\title{
Synthesis, Characterization of Chalcone Containing Methacrylate Polymers: Investigation of Fluorescence, Thermal and Dielectric Properties
}

\section{Mehmet Fatih Coşkun ${ }^{1}$, Adem Şentürk' ${ }^{1}$, Demet Coşkun ${ }^{1}$}

${ }^{1}$ Fırat Üniversitesi, Fen Fakültesi, Kimya Bölümü, Elazığ.

Eposta:fcoskun@firat.edu.tr

Geliş Tarihi: 26.05.2016; Kabul Tarihi: 31.08.2016

Keywords

Thermal properties; Dielectric Properties; Chalcone;

Photodimerization;

Fluorescence.

\begin{abstract}
In this study, the (1-benzofurane-2-yl)-3-oxo-prop-1-en-1-yl]-2-methoxyphenyl 2-methyl acrylate monomer were synthesized from the acylation reaction of this compound with methacryloyl chloride that commercially purchased. Free radicalic or atom transfer radical polymerization methods were used for preparation of copolymers. FT-IR, ${ }^{1} \mathrm{H}$ and ${ }^{13} \mathrm{C}-\mathrm{NMR}$ techniques were used for structure characterization of polymers. The thermal behaviors of polymers were relatively investigated by DSC and TGA, and the results were compared with each other. The dielectric behaviors of polymers were investigated as a function of temperature and frequency. The results obtained were associated with their the structures. The spectroscopic properties of the polymers were investigated by UV-Vis and fluorescence spectroscopies. Effects of the solvent polarity on emission measurement were investigated with fluorescence spectroscopy. Under cover of dimerization property of chalcone, the chalcone ended polymer was photodimerizatied.
\end{abstract}

\section{Kalkon İçerikli Metakrilat Polimerlerinin Sentezi, Karakterizasyonu, Termal, Dielektrik ve Floresans Özelliklerinin İncelenmesi}

\author{
Anahtar Kelimeler \\ Termal özellik; Dielektrik özellik; \\ Kalkon; Fotodimerizasyon; \\ Floresans.
}

Özet

Bu çalışmada, (1-benzofuran-2-il)' in vanilin ile reaksiyonundan (1-benzofuran-2-il)-3-(4hidroksi-3-metoksifenil)prop-2-en-1-on sentezlendi. Sentezlenen bu bileşik ile ticari olarak hazır alınan metakriloilklorür ile açilleme reaksiyonundan (1-benzofuran-2-il)-3-okso-prop-1en-1-il]-2-metoksifenil 2-metilakrilat monomeri sentezlendi. Homopolimer ve kopolimerlerin hazırlanmasında serbest radikalik polimerizasyon ve atom transfer radikal polimerizasyon metodları kullanıldı. Yapı karakterizasyonunda ağırlıklı olarak FT-IR, ${ }^{1} \mathrm{H}$ ve ${ }^{13} \mathrm{C}-\mathrm{NMR}$ teknikleri kullanıldı. Polimerlerin termal davranışları karşılaştırmalı olarak DSC ve TGA ile ölçüldü ve sonuçlar birbirleriyle karşılaştırıldı. Ortalama molekül ağırlıkları ve polidispersiteleri GPC ile ölçüldü. Sıcaklık ve frekansın bir fonksiyonu olarak polimerlerin dielektrik davranışları incelendi ve yapılarıyla ilişkilendirildi. Polimerlerin spektroskopik özellikleri UV-Vis ve floresans spektroskopileriyle araştırıldı. Floresans spektroskopisiyle emisyon ölçümleri üzerine çözücü polarlığının etkisi araştııılı. Kalkonun dimerleşme özelliğinden yararlanılarak kalkon uçlu polimer fotodimerleştirildi. 
1. Introductionlt is known that cyclic compounds and their derivatives that include heteroatoms in their structures are being used both in agriculture and in medicine. Benzofurane and its derivatives are included in our lives in various areas. Furane's monobenzene derivaties are 2,3-benzofurane and 3,4 benzofuranes. 2,3-benzofurane (benzofurane) called coumarone is a liquid with a b.p. of $170^{\circ} \mathrm{C}$, it is unstable and easy to be polymerized. The synthetic resin obtained from coumarone can be used as a paint additive.

Polymers that have reactive functional groups are of great importance from both the academic and industrial perspective. Because their polymer structures are compatible with base modifications to obtain macromolecules with specific synthesis applications, photopolymers are used by considering the characteristics of the macromolecules and photosensitive groups. Among these, polymers that have functional groups that may be photocrossling such as calgon, thymine or coumarine represent an active research area in the polymer science due to their technological importance in photolithography

(Jeong et al. 2005), non-linear optical materials (Zhang et al. 1999), advanced microelectronic (Mizoguchi and Hasegawa 1996), liquid crystal materials (Song et al. 2002) and electrophotographic coatings (Allen et al. 1998) areas. Chalcone and its derivatives attract attention in the organic and medical areas due to their photophysical and photochemical behaviors. It was stated that many natural and synthetic compounds that include chalcone cycles have a wide fluorescent and biological activity in the visible area (Trenor et al. 2004). Chalcone derivaties are used as the blue light area in a commercial sense in a wide application area due to their strong fluorescent specialties in the UV and visible area. It is estimated that methacrylate polymers that have chalcone derivatives will have a commercial potentialas a good UV absorbent in the $250-400 \mathrm{~nm}$ range.

In the studies on the dielectric characteristics of polymers, generally the changes in dielectric constant and dielectric losses depending on the frequency and temperature were observed
(Tamilvanan et al. 2007; Santhi et al. 2006; Park et al. 2013). Usually the dielectric constant of polymers is greater than 2 , and it changes in accordance with frequency and temperature. Polymers that include polar groups show dielectric properties. Dielectric characteristics of a polymer are usually characterized with dielectric constant. This concept also shows the degree of polarization in a material. Degree of polarization is dependent on the intensity and size of the dipoles that occur in a material and are guided by the external electrical field.

\section{Materials and Methods}

İobuthyl methacrylate (IBMA), methyl methacrylate (MMA) and ethyl methacrylate (EMA) (Aldrich) were distilled under vacuum before use. CuBr, 2,2'-bipyridyne (bpy), 2,2'azobisisobutyronitrile (AIBN), acetone, methanol, methacryloyl chloride, 1,4-dioxane and ethanol (Fluka) were used without further purification.

\subsection{3-(3-Methoxy-4-hydroxyphenyl)-1- (benzofurane-2-yl)-2-propen-1-one (BFHM)}

This compound was synthesized according to literature (Coskun, 2008).

\section{2. (1-benzofurane-2-yl)-3-oxo-prop-1-en-1-yl]- 2-methoxyphenyl-2-methylmethacrylate (BFMMA)}

The solution of 1-( 1-benzofuran-2-yl )-3-( 4hidroxy-3-methoxyphenyl ) prop-2-en-1-on in acetone ( $1 \mathrm{~g} ; 0.003 \mathrm{mmol}$ ) was added to the three neck reaction flask and $\mathrm{K}_{2} \mathrm{CO}_{3}(0.47 \mathrm{G}$; $0.003 \mathrm{mmol}$ ) was added to the reaction flask. Reaction mixture was located in ice bath and stirred in order to keep temperature between 0 5 degree of Celcius. After 30 minutes, solution of metakriloilklorur in acetone $(0.35 \mathrm{ml} ; 0.35 \mathrm{~g}$; $0.003 \mathrm{mmol}$ ) was added dropwise during 30 minutes. Reaction mixture was stirred at room temperature for 24 hours. Solvent was removed under evaporator and precipitate was obtained in water and filter out. The precipitate was crystalized in methanol. 


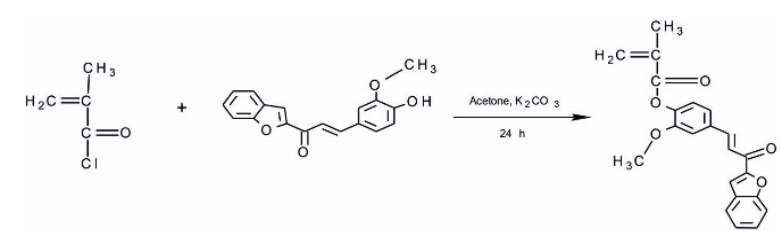

Fig 1. Synthesis of BFMMA

Polymerization tube was purged with Argon and dried under vacuum. $\mathrm{CuBr}(0.008 \mathrm{~g} ; 0.00005$ $\mathrm{mmol}$ ) and 2,2' - bipyridine ( $0.0174 \mathrm{~g} ; 0.001$ $\mathrm{mmol}$ ) were added as catalyst to the tube respectively and purged with Argon. 2bromoethylacatate was added as an initiator and dark red color formation was observed in the complex. The monomer of [3-(1- benzofuran-2-yl3-oxo-prop-1-en-1-yl ]-2-methoxyphenyl-2methylacrylate and (MMA) methylmetacyrlate were added to complex and mixture was purged with Agon for 10 minutes. The tube was sealed and located into $120{ }^{\circ} \mathrm{C}$ oil bath. Copolymerization was started and took 100 hours. Copolymer was dissolved in dichloromethane and precipitated in methanol gradually. This step was repeated for purification. Filtered copolymer was dried at room temperature and the under vacuum at 40 ${ }^{\circ} \mathrm{C}$ for 24 hours. Copolymer was characterized by FT-IR, GPC, ${ }^{1} \mathrm{H}-\mathrm{NMR}$ and DSC.

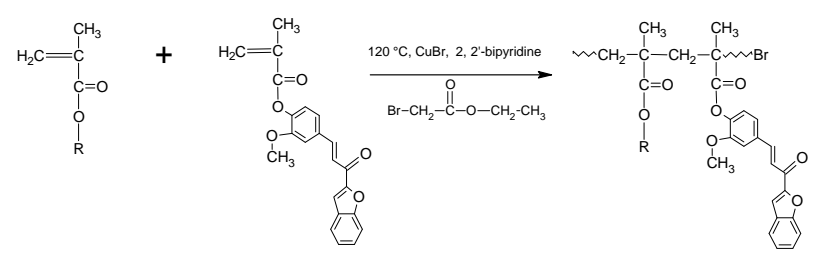

Fig 2. Synthesis of copolymers by atom transfer radical polymerization

The solution of [3-(1-benzofuran-2-yl)-3-oksoprop-1-en-1-yl]-2-methoxyphenyl-2-

methylacrylate $(0.001 \mathrm{mmol})$ in 1,4-dioxane $(2 \mathrm{ml}$ ) was added to rubber sealed polymerization tube and then AIBN ( $0.00001 \mathrm{mmol}$ ) was added as an initiator. Prepared mixture was stayed at $60{ }^{\circ} \mathrm{C}$ oil bath for 7 hours. Obtained polymer mixture was diluted in dichloromethane and precipitated in methanol. Same solvent system was used for precipitation and repeated two times. Firstly, precipitated polymer was dried at room temperature and then under vacuum at $40{ }^{\circ} \mathrm{C}$ for 24 hours. The structure of polymer was characterized by FT-IR, ${ }^{1} \mathrm{H}-\mathrm{NMR}$ and DSC.

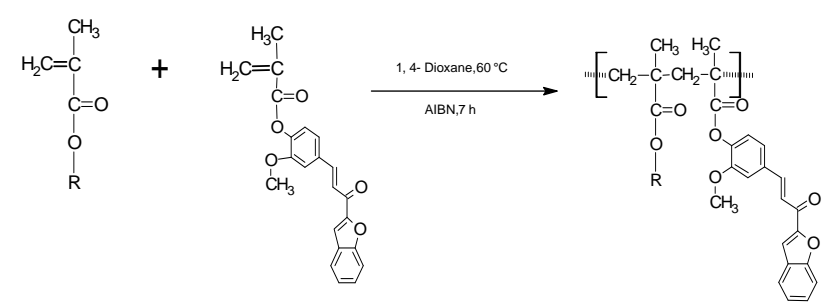

Fig 3. Synthesis of copolymers by free radicalic polymerization

\subsection{Thermal Characterization}

The glass-transition temperatures $(\mathrm{Tg})$ of macroinitiator and all the copolymers were determined from the inflection points onthe differential scanning calorimetry (DSC) curves (Fig. 4).

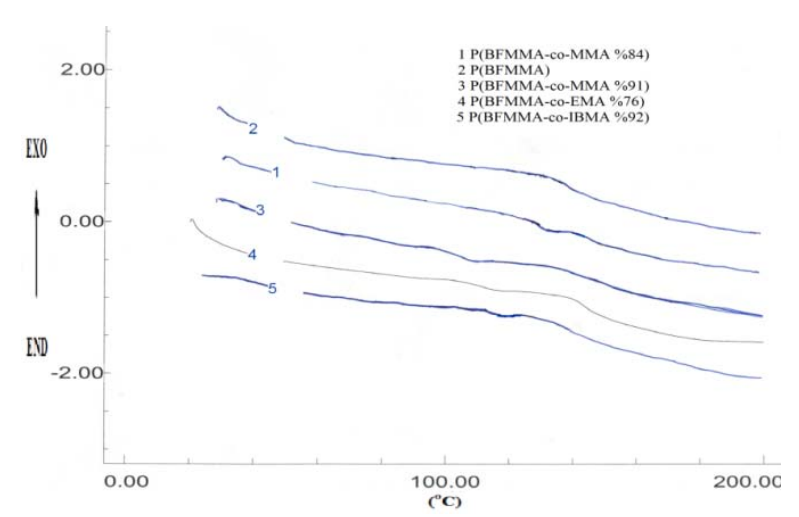

Fig 4. DSC curves of Homo- and copolymers

To examine the thermal stability of these polymers, the TGA curves are recorded under nitrogen flow.

\subsection{Dielectric Constant Values}

The dielectric constant $(\dot{\varepsilon})$ is a measure of the influence of a particular dielectric on the capacitance of a condenser. The dielectric constant value tells how much smaller or bigger the space gets.

\section{Results and Discussion}

Methylmethacrylate monomer was used to create copolymers from BFMMA monomer. 
Copolymerization was done through the Atom Tranfer Radical Polymerization (ATRP) method. The IR spectrum of P(BFMMA-ko-MMA\%84) is shown in Fig.5. The bands around $1147 \mathrm{~cm}^{-1}$ in the copolymer structure show the $\mathrm{C}-\mathrm{O}$ strain in the furan cycle in the calcone, the bands around $1731 \mathrm{~cm}^{-1}$ show the $\mathrm{C}=0$ group in the MMA accumulation in the copolymer compound. The new peak observed in $3.61 \mathrm{ppm}$ in the ${ }^{1} \mathrm{H}-\mathrm{NMR}$ spectrum of $\mathrm{P}(\mathrm{BFMMA-ko-MMA} \% \mathrm{84})$ belongs to $\mathrm{OCH}_{3}$ protons.

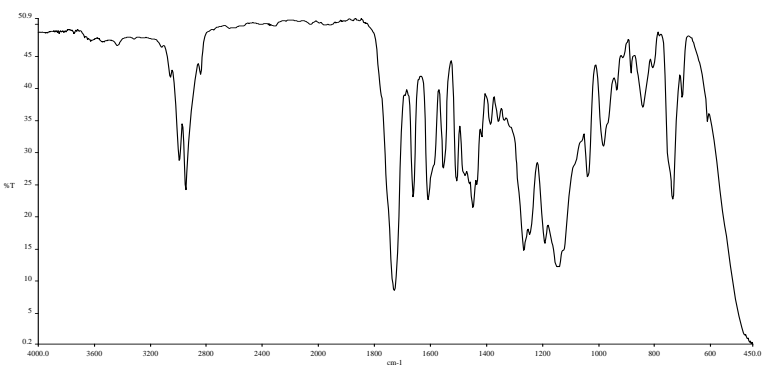

Fig.5 IR Spectrum of P(BFMMA-ko-MMA\%84)

In order to create a series of polymers from the BFMMA monomer, methylmethacrylate, ethylmethacrylate, isobuthylmethacrylate monomers were used. Copolymerization was done through the free radical polymerization method. IR spectrums of P(BFMMA-koMMA\%91), P(BFMMA-ko-EMA \%76) and P(BFMMA-ko-IBMA\%92) are shown and compared in Fig.6. The bands around 1143-1152 $\mathrm{cm}^{-1}$ in the copolymer structure show the $\mathrm{C}-\mathrm{O}$ strain in the furan cycle in the chalcone, while the bands around $1729-1727 \mathrm{~cm}^{-1}$ show the ester $\mathrm{C}=\mathrm{O}$ group in the copolymer compound. The signal in $3.6 \mathrm{ppm}$ in the ${ }^{1} \mathrm{H}-\mathrm{NMR}$ spectrum of P(BFMMA-ko-MMA \% 91) belongs to the $\mathrm{OCH}_{3}$ protons of MMA (Fig.7) , the signal in $4.05 \mathrm{ppm}$ in the ${ }^{1} \mathrm{H}-\mathrm{NMR}$ spectrum of P(BFMMA-ko-MMA \% 76) belongs to the $\mathrm{OCH}_{2}$ protons of EMA (Fig.8) and the signal in $3.7 \mathrm{ppm}$ in the ${ }^{1} \mathrm{H}-\mathrm{NMR}$ spectrum of $\mathrm{P}$ (BFMMA-ko-MMA \% 92) belongs to the $\mathrm{OCH}$ protons of IBMA (Fig.9). These results are in line with the values presented in the literature (Bezgin, 2011).

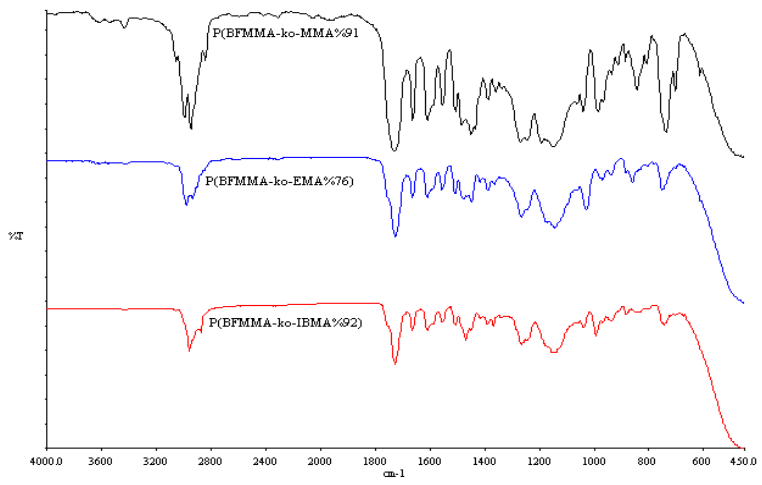

Fig.6 IR Spectra of Copolymers

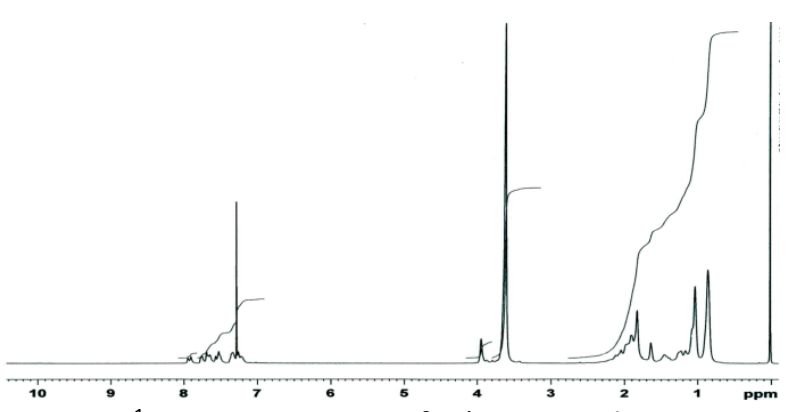

Fig.7 ${ }^{1} \mathrm{H}-\mathrm{NMR}$ Spectrum of P( BFMMA -ko-MMA \% 91) $\left(\mathrm{CDCl}_{3}-\mathrm{d}_{6}\right)$

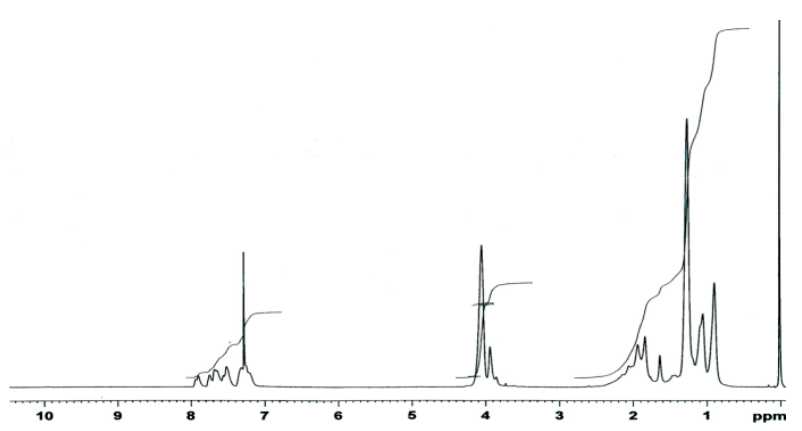

Fig.8 ${ }^{1} \mathrm{H}-\mathrm{NMR}$ Spectrum of $\mathrm{P}(\mathrm{BFMMA}$-ko-EMA \% 76) $\left(\mathrm{CDCl}_{3}-\mathrm{d}_{6}\right)$

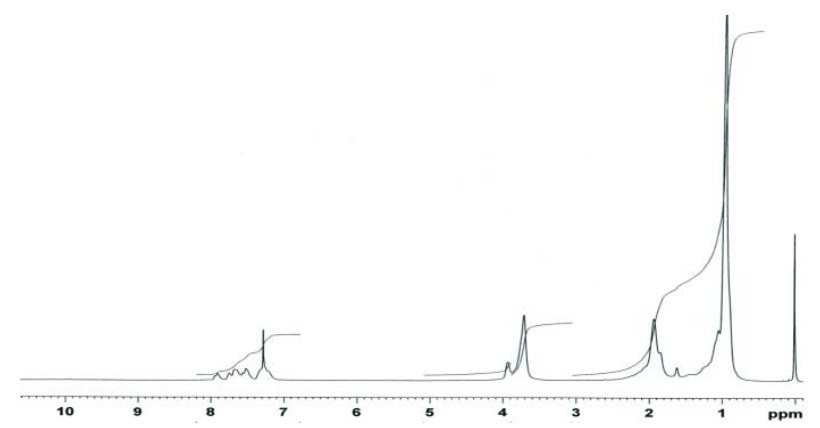

Fig.9 ${ }^{1} \mathrm{H}-\mathrm{NMR}$ Spectrum of P(BFMMA-ko-IBMA \% 92) $\left(\mathrm{CDCl}_{3}-\mathrm{d}_{6}\right)$ 
Thermograms of the homopolymers and copolymers prepared with the BFMMA monomer is presented in Fig.10. Of the homopolymeres, $\mathrm{P}$ (BFMMA), $\mathrm{Tg}$ value is $130^{\circ} \mathrm{C}$, the $\mathrm{Tg}$ values of copolymers is $128{ }^{\circ} \mathrm{C}$ for P(BFMMA-ko-MMA \% 84), $115^{\circ} \mathrm{C}$ for P(BFMMA-ko-MMA \% 91), $110^{\circ} \mathrm{C}$ for P(BFMMA-ko-EMA \% 76) and $107{ }^{\circ} \mathrm{C}$ for P(BFMMA-ko-IBMA \% 92). Lower softening temperature of MMA, EMA and IBMA in comparison with homopolymers is reflecting on the copolymers.

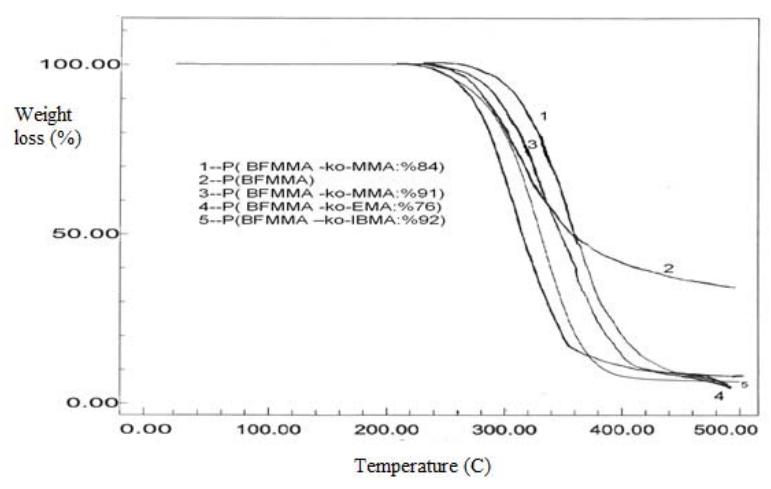

Fig.10 TGA curves of Homo- and copolymers

In this study, first the polymers were given a pellet shape under 4 tons of pressure through a disc, and certain parameters such as its capacitance values (Cp) and dielectric factor (DF) were measured with golden conductors. It was observed that dielectric constants of polymers decrease in increasing frequencies. The decrease in the dielectric constant from $1 \mathrm{kHz}$ to $2 \mathrm{kHz}$ is approximately $5 \%$. This inclination was reported in several studies (Signh and Gupta 1998; Rao et al. 2000). It was observed that polymer capacitance values initially increase in increasing frequencies, and after exceeding a maximum, starts to decrease and is stabilized in high frequencies. This is an indicator that the interfaces can be polarized. It was observed that the dielectric constant and dielectric loss values of polymers decrease in increasing frequencies and do not change after a certain point (Fig.11fig.14).

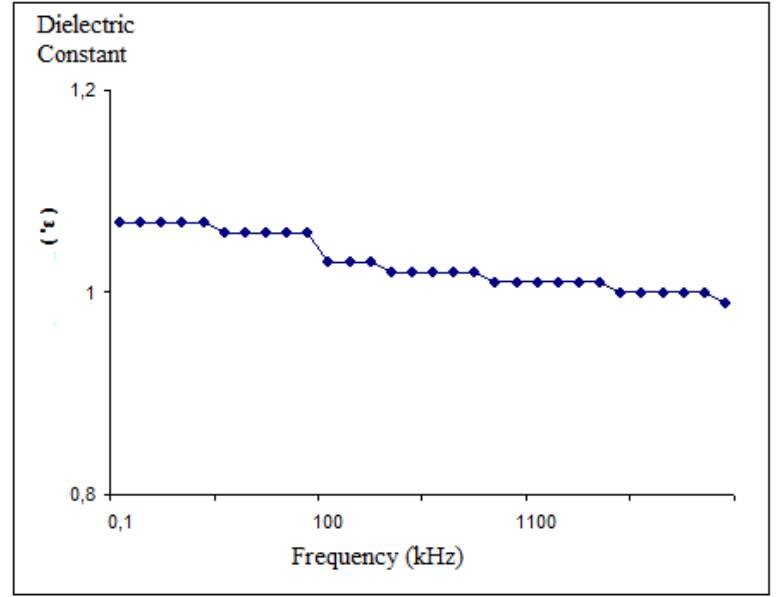

Fig.11 Variation of the dielectric constants with frequency for homopolymer

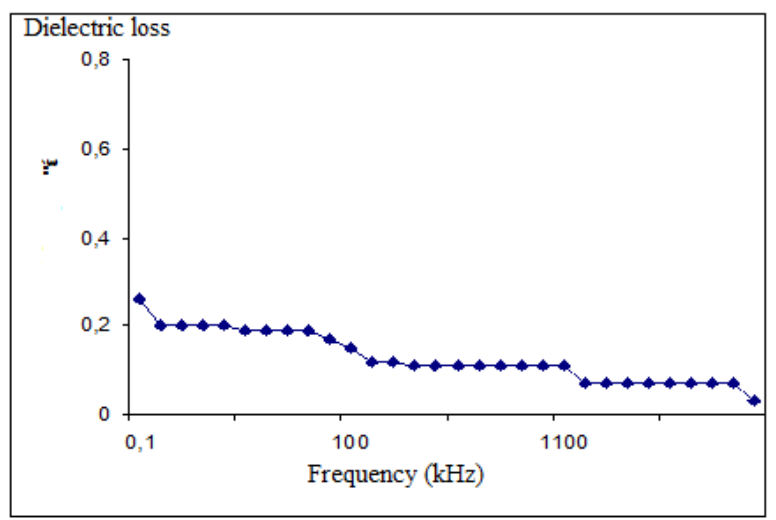

Fig.12 Variation of the dielectric loss with frequency for homopolymer

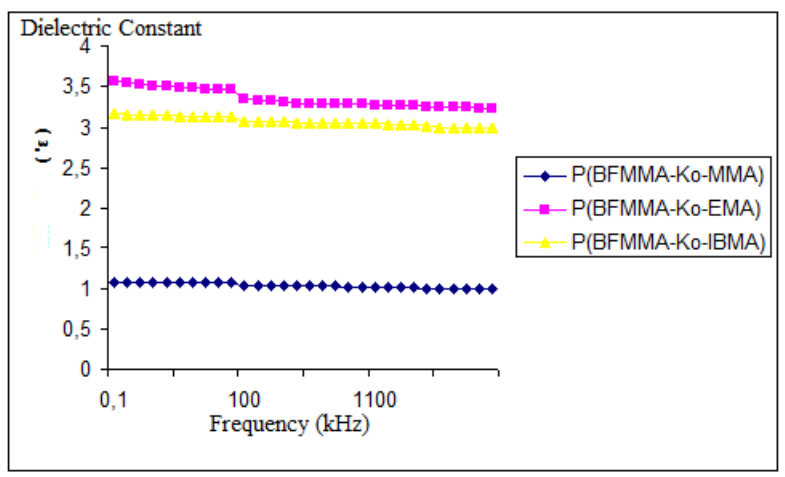

Fig.13 Variation of the dielectric constants with frequency for copolymers 


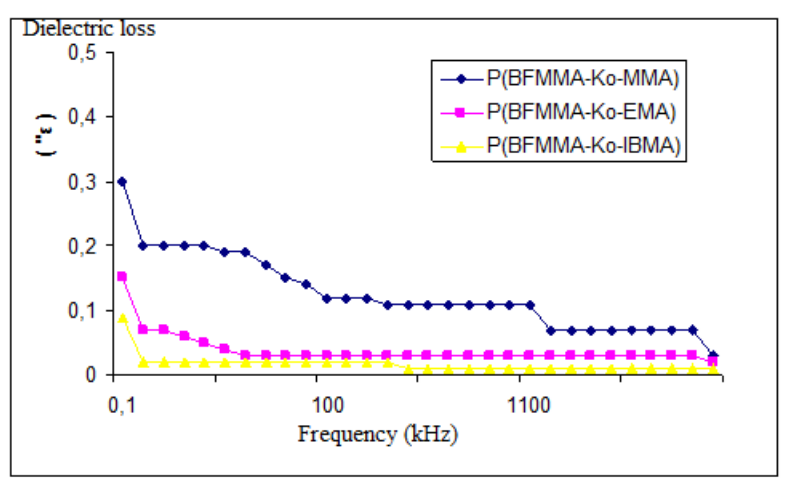

Fig.14 Variation of the dielectric loss with frequency for copolymers

Polarization occurs in alternative areas to move polymer chains in still and frozen polymer molecules in glass transition temperature as a capacitor. It was observed that dielectric constant and dielectric loss values in polymers in glass transition temperature rapidly increase. Accordingly, it can be said that it is an outcome of heat and polarization in the segments in the polymer molecules (Fig.15- fig.16).

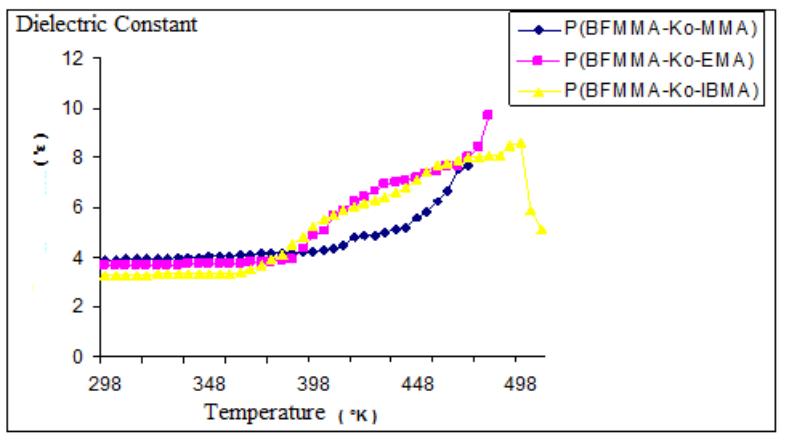

Fig.15 Variation of dielectric constants of polymers with temperature

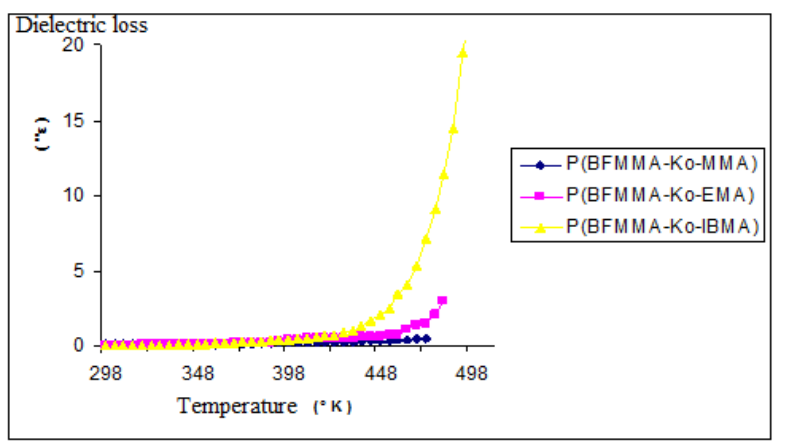

Fig.16 Variation of dielectric loss factor of polymers with temperature
The photodimerization reaction of copolymers of BFMMA prepared with MMA under the UV light was shown in Fig.17. The IR spectrum of the polymers that were beamed in 6 hours intervals are shown in Fig.18. In the IR spectrum, a decrease in the $1660 \mathrm{~cm}^{-1} \mathrm{C}=\mathrm{C}$ area and a shift in the $1731 \mathrm{~cm}^{-1}$ ester carbonyl were observed. The GPC measurement was presented in Fig.19 and its evaluation was given in table.1. It was observed in the GPC measurements that molecular weight increased from $6000 \mathrm{~g} / \mathrm{mole}$ to $10134 \mathrm{~g} / \mathrm{mole}$. From this, we can say that the (BFMMA-ko-MMA) copolymers have been photodimerized (Selvam et al. 2005). The decrease observed in the peak strength between $360-370 \mathrm{~nm}$ is a strong proof of photodimerization (Balaji et al. 2004).

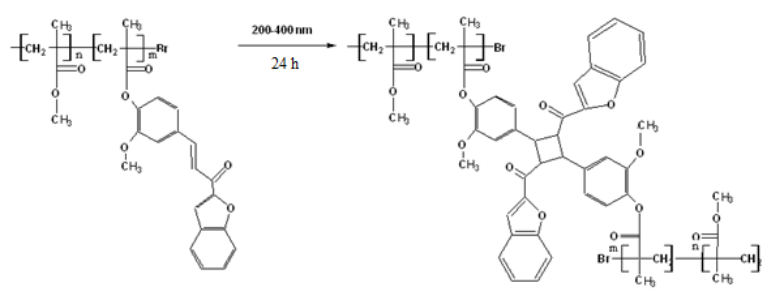

Fig.17 Photodimerization reaction of P( BFMMA-koMMA \% 84)

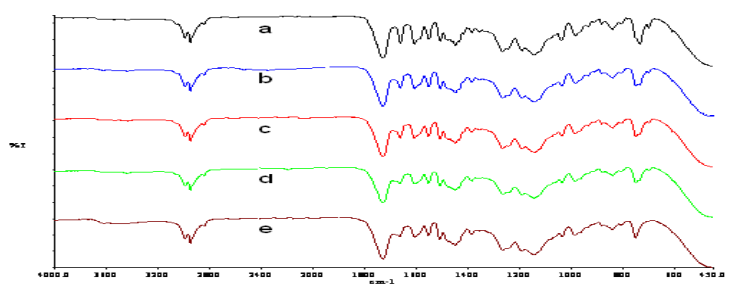

Fig.18 (a) P( BFMMA-co-MMA\%84), (b) irradiated $6 \mathrm{~h}$, (c) irradiated $12 \mathrm{~h},(\mathrm{~d})$ irradiated $18 \mathrm{~h},(\mathrm{e}) \mathrm{IR}$ spectrum of $24 \mathrm{~h}$ irradiated polymer 

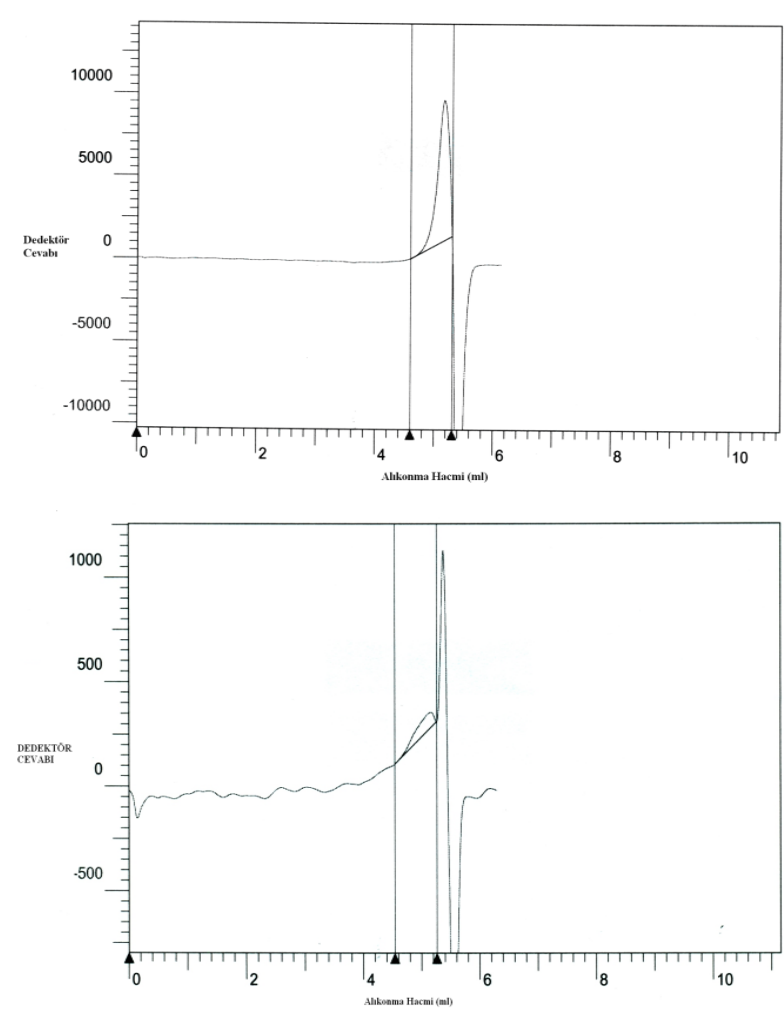

Fig.19 GPC curves of P( BFMMA-ko-MMA\%84) and it's Dimer

Table 1. GPC curve evaluation of P( BFMMA-koMMA\%84) and it's Dimer

The spectrums of BFMMA and copolymers prepared by MMA, EMA and IBMA that have different polarities such as 1,4 dioxane, dichloromethane, dimethylsulfoxide and chloroform were presented in Fig. 20-23. When the fluorescence behaviors are analyzed, it was observed that as the compounds are polarized, they shift to lower wavelengths in polar solvents as the polarization of the solvent increase, at the same time the conjugation increase in the compound, the polarity and the emission wavelengths shift to higher wavelengths (shift to red) (Unal, 2008).

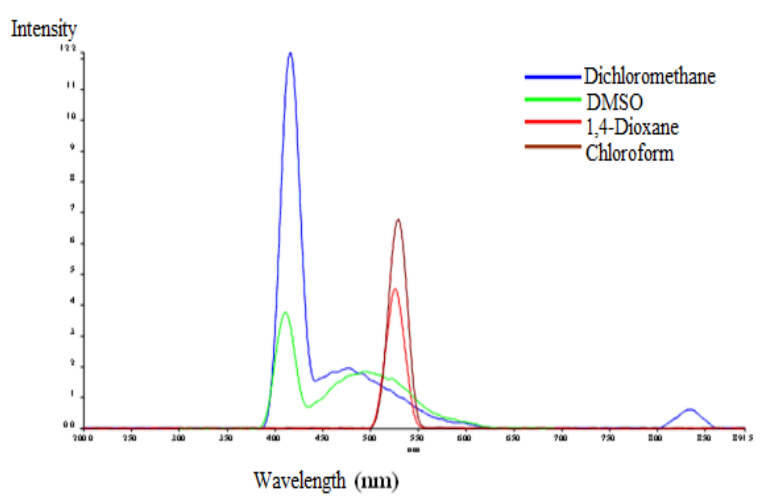

Fig.20 Fluorescence Spectrum of P(BFMMA-ko-MMA $\% 91,10^{-6} \mathrm{M}$ )

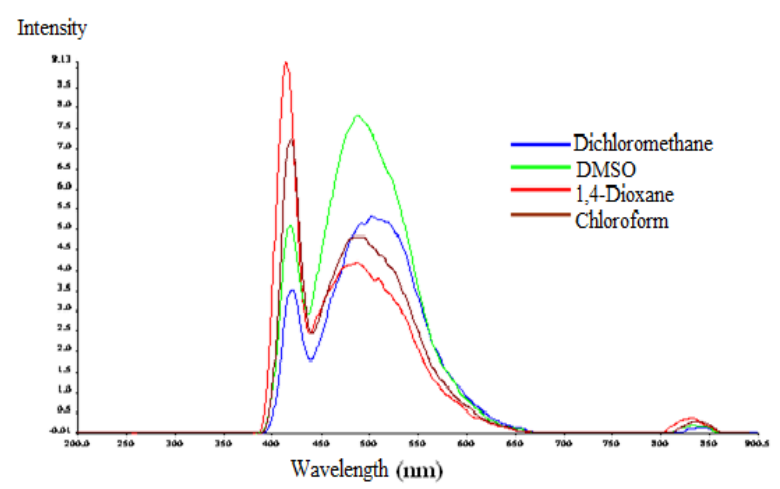

Fig.21 Fluorescence Spectrum of P(BFMMA-ko-MMA $\left.\% 84,10^{-6} \mathrm{M}\right)$

\begin{tabular}{|l|c|c|c|c|c|}
\hline Polymers & Mn & Mw & Mz & Mv & HI \\
\hline $\begin{array}{l}\text { P( BFMMA-ko- } \\
\text { MMA\%84) }\end{array}$ & 6000 & 7450 & 10197 & 7450 & 1.24 \\
\hline $\begin{array}{l}\text { P( BFMMA-ko- } \\
\text { MMA\%84)(Irradiated) }\end{array}$ & 10134 & 15172 & 23592 & 5172 & 1.49 \\
\hline
\end{tabular}

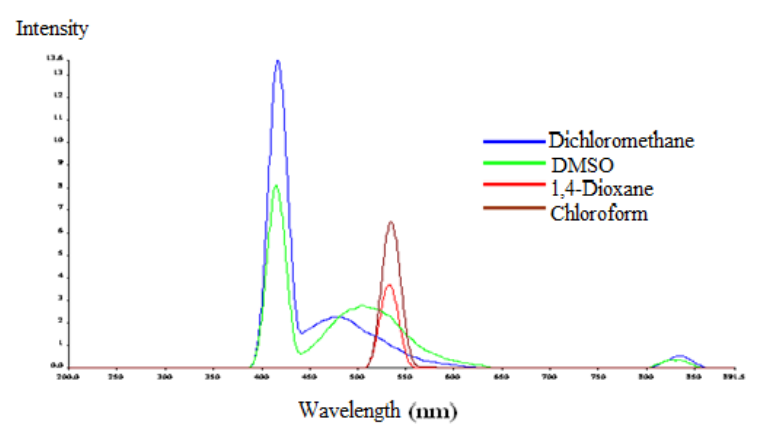

Fig.22 Fluorescence Spectrum of P(BFMMA-ko-EMA \% $\left.76,10^{-6} \mathrm{M}\right)$ 


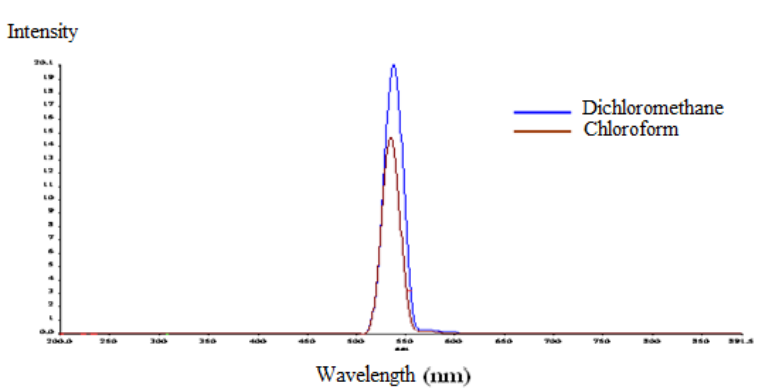

Fig.23 Fluorescence Spectrum of P(BFMMA-ko-IBMA

\begin{tabular}{|c|c|c|c|c|c|c|c|c|}
\hline \multirow[b]{2}{*}{ Polymers } & \multicolumn{4}{|c|}{$\lambda_{\text {max.em.1 } 1(\mathrm{~nm})}$} & \multicolumn{4}{|c|}{$\lambda_{\text {max.em.2 }(\mathrm{nm})}$} \\
\hline & $\mathbf{a}$ & b & c & $d$ & a & b & c & $d$ \\
\hline $\begin{array}{l}\text { P(BFMMA- } \\
\text { ko- } \\
\text { MMA\%91) }\end{array}$ & 416 & 530 & 412 & 536 & 476 & -- & 492 & -- \\
\hline $\begin{array}{l}\text { P(BFMMA- } \\
\text { ko- } \\
\text { MMA\%84) }\end{array}$ & 425 & 427 & 426 & 428 & 495 & 505 & 500 & 498 \\
\hline $\begin{array}{l}\text { P(BFMMA- } \\
\text { ko- } \\
\text { EMA\%76) }\end{array}$ & 420 & 540 & 418 & 545 & 478 & -- & 504 & -- \\
\hline $\begin{array}{l}\text { P(BFMMA- } \\
\text { ko- } \\
\text { IBMA\%92) }\end{array}$ & 544 & -- & -- & 548 & -- & -- & -- & -- \\
\hline
\end{tabular}

$\left.\% 92,10^{-6} \mathrm{M}\right)$

Table 2. Emission values of polymers in Dichloromethane (a), in 1,4 Dioxane (b), in DMSO (c), in Chloroform (d)

\section{Acknowledgements}

The authors thank the Firat University for financial support of this work.

\section{References}

Jeong, J.W., Kwon, Y., Han, Y.S., Park, L.S., 2005. Electroluminescent property and photolithographic process of photosensitive random copolymers. Molecular Crystals and Liquid Crystals, 443, 59-68.

Zhang, L.Z., Li, Y., Liang, Z.X., Yu, Q.S., Cai, Z.G., 1999. New crosslinked polymer systems with high and stable optical nonlinearity. Reactive and Functional Polymer, 40, 255-262.

Mizoguchi, K., Hasegawa, E., 1996. Photoactive polymers applied to advanced microelectronic devices. Polymers for Advanced Technologies, 7, 471-477.
Song, D.M., Jung, K.H., Moon, J.H., Shin, D.M., 2002. Photochemistry of chalcone and the application of chalcone-derivatives in photoalignment layer of liquid crystal display. Optical Materials, 21, 667-671.

Allen, N.S., Khan, L., Edge, M., Billings, M., Vercs, J., 1998. Studies on UV and thermally radical induced cross-linked polymer networks as charge-transport layers in electrophotographic coating applications. Journal of Photochemistry and Photobiology A: Chemistry, 116, 235-244.

Trenor, S.R., Shultz, A.R., Love, B.J., Long, T.E., 2004. Coumarins in polymers: from light harvesting to photo-cross-linkable tissue scaffolds. Chemical Reviews, 104, 3059-3077.

Tamilvanan, M., Pandurangan, A., Reddy, B.S.R., Subramanian, K., 2007. Synthesis, characterization and properties of photoresponsive polymers comprising photocrosslinkable pendant chalcone moieties. Polymer International, 56, 104111.

Santhi, R., Babu, K.V., Penlidis, A., Nanjundan, S., 2006. Studies on copolymers of 3methacryloyloxystyryl-4'-methylphenyl ketone and methyl methacrylate. Reactive \& Functional Polymers, 66, 1215-1226.

Park, H.H., Choi, Y., Park, D.J., Cho, S.Y., Yun, Y.S., Jin, H.J., 2013. Enhanced dielectric properties of electrospun titanium dioxide/polyvinylidene fluoride nanofibrous composites. Fibers and Polymers, 14(9), 1521-1525.

Coskun, D., Ahmedzade, M., 2008. 3-(Substituted aryl)-1-(benzofuran-2-yl)-2-propenones, Part 1: synthesis and characterization of some novel chalcones. Synthetic Communications, 38, 3613-3622.

Bezgin, F., 2011. Synthesis of polymers containing coumarin spectroscopic and dielectric properties. PhD Thesis, University of Firat Graduate School of Sciences, Elazig.

Singh, K.P., Gupta, P.N., 1998. Study of dielectric relaxation in polymer electrolytes. European Polymer Journal, 34, 1023-1029.

Rao, V., Ashokan, P.V., Shridhar, M.H., 2000. Studies of dielectric relaxation and ac conductivity in cellulose acetate hydrogen 
phthalate-poly (methyl methacrylate) blends. Materials Sciences and Engineering: A, 281, 213-220.

Selvam, P., Babu, K.V., Penlidis, A., Nanjundan, S., 2005. Studies on photocrosslinkable copolymers of 4-methacryloyloxyphenyl-3 ',4 '-dimethoxystyryl ketone and methyl methacrylate. European Polymer Journal, 41, 831-841.

Balaji, R., Grande, D., Nanjundan, S., 2004. Photoresponsive polymers having pendant chlorocinnamoyl moieties: synthesis, reactivity ratios and photochemical properties. Polymer, 45, 1089-1099.

Unal, M., 2008. Some Benzimidazole Derivative Fluorimetric Investigation of Properties. Ph Thesis, University of Selcuk Graduate School of Sciences, Konya. 